\title{
Environmental triggers and avoidance in the management of asthma
}

\author{
Clarisse Gautier' \\ Denis Charpin ${ }^{1,2}$ \\ 'Department of Pulmonology and \\ Allergy, North Hospital, ${ }^{2}$ Faculty of \\ Medicine, Aix-Marseille University, \\ Marseille, France
}

This article was published in the following Dove Press journal:

Journal of Asthma and Allergy

7 March 2017

Number of times this article has been viewed

Correspondence: Denis Charpin Clinique des bronches, allergie et sommeil, Hôpital Nord, Chemin des Bourrelly, 13015 Marseille, France

Tel +33491968631

Fax +33491968902

Email denis-andre.charpin@ap-hm.fr
Abstract: Identifying asthma triggers forms the basis of environmental secondary prevention. These triggers may be allergenic or nonallergenic. Allergenic triggers include indoor allergens, such as house dust mites (HDMs), molds, pets, cockroaches, and rodents, and outdoor allergens, such as pollens and molds. Clinical observations provide support for the role of HDM exposure as a trigger, although avoidance studies provide conflicting results. Molds and their metabolic products are now considered to be triggers of asthma attacks. Pets, dogs, and especially cats can undoubtedly trigger asthmatic symptoms in sensitized subjects. Avoidance is difficult and rarely adhered to by families. Cockroach allergens contribute to asthma morbidity, and avoidance strategies can lead to clinical benefit. Mouse allergens are mostly found in inner-city dwellings, but their implication in asthma morbidity is debated. In the outdoors, pollens can induce seasonal asthma in sensitized individuals. Avoidance relies on preventing pollens from getting into the house and on minimizing seasonal outdoor exposure. Outdoor molds may lead to severe asthma exacerbations. Nonallergenic triggers include viral infections, active and passive smoking, meteorological changes, occupational exposures, and other triggers that are less commonly involved. Viral infection is the main asthma trigger in children. Active smoking is associated with higher asthma morbidity, and smoking cessation interventions should be personalized. Passive smoking is also a risk factor for asthma exacerbation. The implementation of public smoking bans has led to a reduction in the hospitalization of asthmatic children. Air pollution levels have been linked with asthmatic symptoms, a decrease in lung function, and increased emergency room visits and hospitalizations. Since avoidance is not easy to achieve, clean air policies remain the most effective strategy. Indoor air is also affected by air pollutants, such as cigarette smoke and volatile organic compounds generated by building and cleaning materials. Occupational exposures include work-exacerbated asthma and work-related asthma.

Keywords: asthma, environment, triggers, avoidance, prevention

\section{Introduction}

Over the past several years, a wide range of epidemiological, clinical, and experimental studies have led to major advances in the field of respiratory allergies. A wide array of risk factors play a multifaceted role, guiding the secondary prevention approach. In this review, we will not elaborate on potential protective factors associated with the "hygiene hypothesis", rather we will focus on allergenic and nonallergenic triggers (Table 1). ${ }^{1}$ For each of these, after a short definition, we will review studies that suggest or prove their involvement, and when appropriate, we will then evaluate the outcomes of avoidance procedures. 
Table I Self-reported asthma triggers as ranked by the proportion of participants who have experienced the trigger and by how frequently the trigger was reported

\begin{tabular}{|c|c|c|c|}
\hline Triggers & $\begin{array}{l}\text { Percentage of } \\
\text { participants who } \\
\text { have ever } \\
\text { experienced, } n=\mid 202\end{array}$ & Triggers & $\begin{array}{l}\text { Frequency } \\
\text { (weeks/year), } \\
n=1202\end{array}$ \\
\hline Dust or dusting & 72 & Dust or dusting & 18.6 \\
\hline Cold, flu, infections, and sinusitis & 6 & Smoking (eg, cigarettes or cigars) & 14.2 \\
\hline Coughing & 68 & Coughing & 11.3 \\
\hline Smoking (eg, cigarettes or cigars) & 60 & Exercise & II.I \\
\hline Smoke & 59 & Vacuum cleaning & 10.1 \\
\hline Smog and air pollution & 58 & Perfumes, hairspray, or air fresheners & 10.0 \\
\hline Exercise & 54 & Animals & 9.6 \\
\hline Strong odors & 54 & Smog and air pollution & 9.5 \\
\hline Weather changes & 51 & Smoke & 9.0 \\
\hline Mold and mold spores & 51 & Emotions & 8.2 \\
\hline Animals & 50 & Cleaning products & 8.2 \\
\hline Damp places & 48 & Damp places & 8.1 \\
\hline Humidity & 48 & Weather changes & 8.0 \\
\hline Perfumes, hairspray, or air fresheners & 48 & Humidity & 7.9 \\
\hline Grass, mowing the lawn, and weeds & 47 & Strong odors & 7.6 \\
\hline Cold air & 45 & Mold and mold spores & 7.4 \\
\hline Emotions & 43 & Cold air & 7.2 \\
\hline Cleaning products & 42 & Grass, mowing the lawn, and weeds & 6.9 \\
\hline Vacuum cleaning & 41 & Lying flat & 6.8 \\
\hline Feathers & 40 & Cold, flu, infections, and sinusitis & 6.7 \\
\hline Air conditioning & 37 & Air conditioning & 5.8 \\
\hline Lying flat & 29 & Feathers & 5.4 \\
\hline Your work environment & 25 & Your work environment & 4.8 \\
\hline Rain & 19 & Rain & 3.4 \\
\hline Food and drinks of food colorings & 19 & Food and drinks of food colorings & 3.1 \\
\hline Alcohol & 18 & Indigestion or heartburn & 2.8 \\
\hline Other medications & 18 & Alcohol & 2.4 \\
\hline Indigestion or heartburn & 17 & Aspirin & 2.1 \\
\hline Eating out at particular restaurants & 15 & Other medications & 2.0 \\
\hline Aspirin & 15 & Eating out at particular restaurants & 1.8 \\
\hline Hormonal changes & 14 & Hormonal changes & 1.8 \\
\hline Paracetamol & 12 & Paracetamol & 1.6 \\
\hline
\end{tabular}

Note: Adapted from Price D, Dale P, Elder E, Chapman KR. Types, frequency and impact of asthma triggers on patients' lives: a quantitative study in five European countries. J Asthma. 20I4;5।(2):I27-135. @ 2014 The Author(s). Published by Taylor \& Francis.'

\section{Allergenic triggers Indoor allergens}

\section{House dust mite (HDM) allergens}

HDMs are ubiquitous pyroglyphidae that live in human dwellings. The mite's gut contains potent digestive enzymes, notably proteases that persist in the feces, and these are thought to induce allergic sensitization and asthma. Their proliferation is favored by high indoor humidity and elevated temperatures. Mite allergens are classified into 33 groups, listed in the systematic World Health Organization (WHO) and the International Union of Immunologic Societies (IUIS).

Arguments in support of their involvement as triggers of asthma attacks include an association between HDM allergen exposure and asthma outcomes (and in some studies, a dose-response relationship), such as asthmatic symptoms and the requirement for medication in allergic asthmatic patients. ${ }^{2,3}$ The relationship with visits to the emergency department has provided conflicting results, as the association reported in earlier studies ${ }^{4}$ was not found in a more recent one. ${ }^{5}$

There have been numerous studies on avoidance procedures in regard to HDM and HDM allergens since their discovery in the late 1960s. These studies have led to metaanalyses. Four meta-analyses on HDM avoidance for asthma by Gotzsche and Johansen, which were published in 1998, 2001, 2004, and 2008, concluded that avoidance was of no benefit to asthmatic patients. ${ }^{6}$ Custovic and $\mathrm{Wijk}^{7}$ concluded 
that there is currently inadequate evidence to advocate allergen avoidance in adults, whereas these interventions may be of some benefit in children (Table 2). Platts-Mills has criticized these meta-analyses on the basis that this analytical approach is inadequate because allergen avoidance protocols are multifaceted and personalized and are hence difficult to standardize. ${ }^{8}$ Apart from these statistical shortcomings in the meta-analyses, there are also a number of biological issues that need to be considered. First, which biological parameter is the most representative of patient exposure? Tovey et $\mathrm{al}^{9}$ suggest that in-bed exposure accounts for only $9 \%$ of the total exposure. Second, dust collected from the homes of patients includes many other air contaminants besides HDMs and HDM allergens, such

Table 2 Practical measures for reducing dust mite and pet allergen levels: effect on allergen levels and the clinical effect on symptoms of rhinitis and asthma

\begin{tabular}{|c|c|c|}
\hline Measure & $\begin{array}{l}\text { Effect on } \\
\text { allergen } \\
\text { levels }\end{array}$ & $\begin{array}{l}\text { Clinical } \\
\text { effectiveness }\end{array}$ \\
\hline \multicolumn{3}{|l|}{ House dust mite allergen avoidance } \\
\hline $\begin{array}{l}\text { Encasing mattresses, pillows, and quilts } \\
\text { in impermeable covers }\end{array}$ & $\mathrm{lb}$ & $\begin{array}{l}\text { la - no effect in } \\
\text { adults } \\
\text { lb - some effect } \\
\text { in children }\end{array}$ \\
\hline $\begin{array}{l}\text { Washing bedding in the hot cycle } \\
\left(55^{\circ} \mathrm{C}-60^{\circ} \mathrm{C}\right)\end{array}$ & Ilb & IV \\
\hline Replacing carpets with hard flooring & $\mathrm{lb}$ & IV \\
\hline Acaricides and/or tannic acid & III & IV \\
\hline $\begin{array}{l}\text { Minimizing dust accumulating objects } \\
\text { in closed cupboards }\end{array}$ & IV & IV \\
\hline $\begin{array}{l}\text { Vacuum cleaners with integral HEPA } \\
\text { filter and double thickness bags }\end{array}$ & Illb & IV \\
\hline $\begin{array}{l}\text { Removing and hot washing/freezing of } \\
\text { soft toys }\end{array}$ & IV & IV \\
\hline \multicolumn{3}{|l|}{ Pet allergen avoidance } \\
\hline Removing cat/dog from the home & Ilb & IV \\
\hline $\begin{array}{l}\text { Keeping the pet out of the main } \\
\text { living areas and bedrooms }\end{array}$ & Ilb & IV \\
\hline HEPA filter air cleaners & $\mathrm{lb}$ & $\begin{array}{l}\text { la - no effect in } \\
\text { pet allergy }\end{array}$ \\
\hline Washing a pet & Ilb & IV \\
\hline $\begin{array}{l}\text { Replace carpets with linoleum or } \\
\text { wood flooring }\end{array}$ & IV & IV \\
\hline $\begin{array}{l}\text { Vacuum cleaners with integral HEPA } \\
\text { filter and double thickness bags }\end{array}$ & IV & IV \\
\hline
\end{tabular}

Notes: Evidence level graded according to the Scottish Intercollegiate Guidelines Network recommendations: la, evidence obtained from meta-analysis of randomized controlled trials; lb, evidence obtained from at least one randomized controlled trials; llb, evidence obtained from at least one other type of well-designed quasiexperimental study; III, evidence obtained from well-designed nonexperimental descriptive studies, such as comparative studies, correlation studies, and case studies; IV, evidence obtained from expert committee reports or opinions and/or clinical experience of respected authorities. Reproduced from Custovic A, Wijk PG. The effectiveness of measures to change the indoor environment in the treatment of allergic rhinitis and asthma: ARIA update (in collaboration with GA(2)LEN). Allergy. 2005;60(9): I I I 2-I I I 5. Copyright (C Blackwell Munksgaard 2005.?

Abbreviation: HEPA, High efficiency particulate arrestance. as bacteria and endotoxins, molds, glucans originating from mold membranes, mycotoxins, and microbial volatile organic compounds (Table 3 ). ${ }^{10}$ Thus, avoidance procedures directly aimed at HDMs may only provide partial measures. Furthermore, being sensitized to HDMs does not per se mean that HDM allergens play a role in the clinical expression of the disease. Finally, in the context of unhealthy buildings, of which there are many, the building itself generally has one or more defects that are responsible for high indoor humidity that leads to HDMs, mold proliferation, and release of their metabolites. ${ }^{10}$ Programs that have proven to be effective use a multifaceted approach including community health workers, ${ }^{11}$ environmental counseling, therapeutic education, and home remediation. ${ }^{12,13}$

\section{Molds}

Microscopic fungi, or molds, represent one of the main groups of microorganisms present in all buildings. Although there are thousands of mold species, only $\sim 80$ indoor molds are thought to be responsible for adverse health effects in humans.

There have also been a number of epidemiological surveys in regard to this topic. The results of these have been summarized in meta-analyse ${ }^{14-17}$ and in reports from national ${ }^{18,19}$ and international health authorities. ${ }^{20}$ The association between dampness or mold and the impact on health is presented in Table 4. From this, it would appear that these factors are relevant.

There are few published interventional studies regarding dampness and mold in homes. They have been reviewed by Cox-Ganser. ${ }^{21}$ In one study, there were significantly fewer emergency department visits and/or hospitalizations among children in the remediation group compared to those in the control group. In another randomized controlled study performed in the UK, asthma symptoms and asthma medication use declined in the intervention group. A third study involved moving participants into an "asthma friendly, Breathe-Easy Home". Children randomized to move into these houses had more asthma-free days, and fewer of them required health care visits compared to those in the control group.

\section{Pets}

According to market research statistics published by animal food suppliers, $\sim 50 \%$ of families in developed countries have a pet. ${ }^{22-24}$ This figure is the same for families with allergies.

There are as many dogs as cats, although cats are more allergenic than dogs. ${ }^{25}$ 
Table 3 Fungal components and products relevant for indoor air sciences

\begin{tabular}{|c|c|c|}
\hline Fungal agent & Short description & Applications in indoor air research \\
\hline Fragments & $\begin{array}{l}\text { Particles of fungal origin that are smaller than whole spores } \\
\text { (typically }<1 \mu \mathrm{m} \text { ) }\end{array}$ & $\begin{array}{l}\text { May have relevance as exposure agents related to health } \\
\text { effects }\end{array}$ \\
\hline \multirow[t]{3}{*}{ Ergosterol } & Sterol specific to fungal cells & Ergosterol content used as a proxy for fungal biomass \\
\hline & Present in most fungal cells, underrepresented in yeasts & \\
\hline & No specific role as health-relevant agent & \\
\hline \multirow[t]{2}{*}{ Glucans } & $\begin{array}{l}\text { Major structural component of fungal cells }(I-3) \text { - and } \\
(I-6) \text {-linked polymers of D-glucose }\end{array}$ & $\begin{array}{l}\text { Glucans' content is used as a proxy of bioactive portion of } \\
\text { fungal biomass }\end{array}$ \\
\hline & Nonallergenic but possess proinflammatory properties & \\
\hline \multirow[t]{2}{*}{ EPS } & Stable, high molecular weight sugar polymers on the surface & Marker of fungal biomass (mainly Penicillium and Aspergillus) \\
\hline & of fungal cells, produced during growth & No longer widely used \\
\hline Fungal allergens & $\begin{array}{l}\text { Antigenic substances of fungi capable of stimulating an } \\
\text { lgE-mediated response }\end{array}$ & $\begin{array}{l}\text { Indoor exposure and role in health effects insufficiently } \\
\text { known }\end{array}$ \\
\hline MVOC & $\begin{array}{l}\text { Highly volatile low molecular weight chemicals, produced } \\
\text { by growing fungi (and bacteria) as primary and secondary } \\
\text { metabolites } \\
\text { Include alcohols, aldehydes, amines, ketones, terpenes, and } \\
\text { aromatic hydrocarbons } \\
\text { Relatively low toxicity }\end{array}$ & $\begin{array}{l}\text { Recognized as odor of mold } \\
\text { Measurement of MVOCs is not a good indicator of fungal } \\
\text { growth as there are very few VOCs specific to microbial } \\
\text { sources only }\end{array}$ \\
\hline Mycotoxins & $\begin{array}{l}\text { Nonvolatile fungal secondary metabolites with a variety of } \\
\text { chemical structures } \\
\text { Chemically stable and some of them are thermally stable } \\
\text { Many are bioactive and some are acutely toxic by ingestion } \\
\text { May be present airborne attached to other particles }\end{array}$ & $\begin{array}{l}\text { Occurrence in indoor air has been shown } \\
\text { Role as causative agents of symptoms possibly due to } \\
\text { their toxicity and inflammatory potential } \\
\text { Specific studies on their connection to health still lacking }\end{array}$ \\
\hline Fungal nucleic acids & Polymeric macromolecules composed of nucleotides & No relevance as a potential causative agent of health \\
\hline DNA and RNA & $\begin{array}{l}\text { Contains the genetic material of a fungal cell (DNA) or acts in } \\
\text { converting the genetic information (RNA) } \\
\text { Located in the different cellular organelles and the mycoplasm }\end{array}$ & $\begin{array}{l}\text { outcomes } \\
\text { Widely used as a target in DNA-based methods that } \\
\text { are increasingly applied in indoor air research (including } \\
\text { quantitative PCR, DNA fingerprinting, and sequencing } \\
\text { applications) }\end{array}$ \\
\hline
\end{tabular}

Note: Reproduced from Nevalainen A, Täubel M, Hyvärinen A. Indoor fungi: companions and contaminants. Indoor Air. 20I5;25(2): 125-I56. @ 20I4 John Wiley \& Sons A/S. Published by John Wiley \& Sons Ltd. ${ }^{10}$

Abbreviations: EPS, extracellular polysaccharides; IgE, immunoglobulin E; MVOC, microbial volatile organic compounds.

Table 4 Association between excessive humidity/molds and health impact according to the IOM, the WHO, and the ANSES

\begin{tabular}{|c|c|c|c|}
\hline Health authorities & $1 O M^{18}$ & $\mathrm{WHO}^{20}$ & ANSES $^{19}$ \\
\hline $\begin{array}{l}\text { Bronchial symptoms (cough and } \\
\text { wheezing) }\end{array}$ & + & + & + \\
\hline Asthma occurrence & 0 & 0 & $\begin{array}{l}\text { + children } \\
+ \text { occupational } \\
\text { asthma in adults }\end{array}$ \\
\hline Asthma exacerbations & + & + & + \\
\hline Hypersensitivity pneumonia & + & + & + \\
\hline
\end{tabular}

Note: "+" means the association has been acknowledged, and "0" means that it has not.

Abbreviations: ANSES, French Agency for Food, Environment and Occupational Health \& Safety; IOM, Institute of Medicine of the National Academies; WHO, World Health Organization.

Pet allergy can readily be documented based on the clinical history. Skin tests for pet hair and danders (shed skin cells) are not very specific because some allergens from dogs cross-react with the major cat allergen, $\mathrm{Fel} d$ 1. Allergenic particles are small, ranging from 2 to $10 \mu \mathrm{m}$ in size, which allows them to remain airborne and to stick to surfaces and clothing. ${ }^{26,27}$

Avoidance of cat allergens is hard to achieve. Patients who do not have a cat at home will nonetheless encounter cat allergens in many locations because these allergens are ubiquitous. ${ }^{28,29}$ For patients who have a cat at home, the advice is generally to find a different home for the cat. Then, cat allergen levels can be reduced, although even when this advice is followed, while most families fail to adhere to this advice. ${ }^{30}$ Other authors see little point in such measures since even low levels of cat allergens will still cause sensitized patients to react. ${ }^{31}$ When the cat remains in the home, basic avoidance measures do not decrease cat-allergen levels. ${ }^{32,33}$ Several pet companies have marketed the so-called "hypoallergenic cats", although there is no scientific evidence to support this claim. ${ }^{34}$

Dog allergens are found in dog hair, shed skin cells, saliva, and urine. There are no differences between breeds in terms of allergy induction. Dogs are less often responsible for allergic reaction than cats. ${ }^{25}$ Avoidance counseling does not yield better outcomes than with cat allergies. ${ }^{35}$

\section{Cockroaches}

Cockroach allergens are mainly found in the kitchens of lowincome housing. The combination of cockroach allergen exposure and allergic sensitization contributes to asthma morbidity. ${ }^{36}$ 
The environmental control of cockroaches has recently been summarized by a Joint Task Force of three major professional allergy organizations. ${ }^{37}$ Strategies that effectively lower cockroach allergen levels result in a clinical benefit. ${ }^{38}$ They include keeping the kitchen clean, promptly washing the dishes, putting all foods in sealed containers, frequent disposal of the garbage, avoiding leaving food to sit out, and setting roach traps.

\section{Rodents}

Like cockroach allergens, mouse allergens originate from mouse urine, shed skin cells, and hair follicles, and they are mostly found in inner-city dwellings. High levels of allergens may be found in schools and homes, but their relationship with asthma morbidity is still controversial. ${ }^{39,40}$ Integrative pest management has been associated with a reduction in allergen levels in the kitchen and in bedrooms. ${ }^{40}$ Outcomes in terms of a reduction in the use of health care provisions in children are also controversial. ${ }^{41,42}$ Public buildings in France have not been found to contain high levels of mouse allergens. ${ }^{43}$

\section{Outdoor allergens \\ Pollens}

Allergenic pollens are those that are small enough to be transported by the wind. With most patients, allergy to pollen induces rhinoconjunctivitis. Nonspecific bronchial hyperreactivity increases with grass-pollen allergy ${ }^{44}$ as well as with Parietaria pollen allergy during pollination. ${ }^{45}$

In the Copenhagen Allergy Study, it was estimated that a quarter of the subjects who were allergic to pollen also exhibited allergic asthma from pollen, while approximately one-half of the subjects with allergic rhinitis to animals or HDMs also exhibited asthma from animals or HDMs. ${ }^{46}$

Pollen avoidance is only relevant during the time that the offending pollen is airborne, which underscores the importance of a precise allergologic diagnosis. During this time period, patients are advised to - if at all possible - be outdoors only early in the morning or during the late afternoon, because humidity is higher then and the pollen particles tend to stick to anthers. In addition to this, car and home windows should be kept shut. Patients may be advised to turn on their air conditioner, to wear a pollen mask and wraparound glasses, and to take a shower and to wash their hair after being outdoors for an extended period of time. These recommendations follow common sense, although they have not been validated by control experiments.

\section{Outdoor molds}

Alternaria and Cladosporium species are considered to be major outdoor allergens responsible for sensitization, development of rhinitis and asthma, and asthma exacerbation, including life-threatening exacerbations. In contrast, xerophilic species of Penicillium and Aspergillus are involved in allergic diseases as indoor allergens. In regard to indoor allergens, the diagnosis of outdoor mold allergies is difficult because allergenic extracts are not well standardized and most fungal extracts exhibit broad cross-reactivity with taxonomically unrelated fungi. ${ }^{47}$

\section{Nonallergenic triggers}

Viral infections have been implicated in most (>80\%) asthma exacerbations in children. ${ }^{48}$ Such infections are sometimes referred to as the "September epidemic" due to their seasonal pattern. ${ }^{49}$ Rhinoviruses are the most commonly encountered, although other viruses, such as respiratory syncytial virus, enterovirus, coronavirus, and human metapneumovirus, can also be involved. Viruses interact with allergens to induce asthma exacerbation and hospitalization. ${ }^{50}$

Aside from keeping away from infected subjects, vaccination against the flu, and pharmacologic treatment during the first few days following contamination, there are no preventive treatments.

\section{Active smoking}

According to the Centers for Disease Control and Prevention in the USA, $21 \%$ of Americans with asthma are active smokers. ${ }^{51,52}$ Asthmatics who smoke are likely to experience a higher rate of hospitalization than asthmatics who do not smoke. ${ }^{53}$ Another study, performed with pregnant women, demonstrated poor asthma control and increased asthma exacerbations in active smokers and ex-smokers. ${ }^{54}$ Furthermore, inhaled corticosteroids, which represent the most effective currently available treatment for treating chronic asthma, have a reduced efficacy in smokers. ${ }^{55}$

McLeish et al ${ }^{56}$ evaluated smoking cessation in smokers with and without asthma. They concluded that these two groups did not differ in terms of the abstinence rate and smoking relapse, although they did show that smokers with asthma exhibited a slower rate of decline in nicotine withdrawal symptoms and craving over time. Bittner et $\mathrm{al}^{57}$ concluded that providing smoking cessation interventions during hospitalization for asthma exacerbations was an underutilized opportunity. Perret et al ${ }^{58}$ suggested several ways to improve smoking cessation strategies in asthmatic smokers, such as individualized interventions, insisting on "lung age", providing long-term follow-up, and, in the case of adolescents, involving older peers to deliver asthma education. 


\section{Passive smoking}

The relationship between passive smoking and childhood asthma exacerbation and hospitalization is well recognized. In the USA, it is estimated that, on an annual basis, $>200,000$ asthma exacerbations are associated with passive smoking. ${ }^{59}$

The implementation of a public smoking ban in Scotland has reduced the rate of asthma exacerbations. ${ }^{60} \mathrm{~A}$ similar effect was observed in Minnesota (USA) as well as at the national level. ${ }^{61,62}$ This latter survey demonstrated a lower level of second-hand smoke exposure, a decrease in the odds of current asthma symptoms, and a lower risk of visits to the doctor due to severe asthma symptoms. A meta-analysis of 11 eligible studies published between 2008 and 2013 determined that hospital attendance for asthma patients decreased by $10 \%$ following the ban. ${ }^{63}$

\section{Air pollution}

Changes in gaseous and particulate outdoor air pollutants are associated with daily asthmatic symptoms, a decrease in lung function, ${ }^{64,65}$ emergency room visits, and hospitalizations for asthma attacks. ${ }^{66}$ The lag time amounts to 24 hours following the acute episode. In children with moderate persistent asthma, the occurrence of symptoms and the decrease in lung function are more pronounced in those patients who do not follow a maintenance therapy. ${ }^{67}$ Avoidance of outdoor air pollution is hard to achieve because there is no realistic way of avoiding exposure. National authorities do not recommend that asthmatic subjects remain indoors during periods of elevated air pollution because indoor air pollution can in fact be more harmful. When air quality index reaches a certain level, asthmatic patients, and eventually all individuals, should reduce the time spent outdoors and, in particular, avoid exertion in the polluted air. ${ }^{68}$ Other recommendations, such as wearing a dust mask and taking supplemental antioxidants, are unlikely to be effective. ${ }^{69}$ Thus, as stated in this review, sustained clean air policies remain the most effective way to reduce health effects that are related to air pollution.

The impact of volatile organic compounds that are encountered as indoor air pollutants on asthma control is still a matter of debate. ${ }^{70}$ The main indoor air pollutant is cigarette smoke. In Pittsburg, an industrial community with high outdoor air pollution, indoor activities, especially cigarette smoke, are responsible for a large part of the indoor exposure. ${ }^{71}$ Compared to cigarette smoke, e-cigarette vapor produces very small amounts of all by-products. ${ }^{72}$ Indoor chemical air pollution can be lowered by avoiding cookingrelated pollutants, avoiding the use of sprays and other cleaning materials that generate volatile organic compounds
(VOCs), choosing furniture and building material with low VOC emissions, and regular air exchange by natural or mechanical ventilation. These recommendations have been made available to the general public. ${ }^{73}$

\section{Meteorological changes}

An increase in daily temperatures correlated with an increase in emergency room department visits for asthma, especially in patients older than 65 years. ${ }^{74}$ However, cold temperatures also trigger asthma attacks. In general, the effect of cold weather appears to last for several weeks, whereas the effect of hot weather was more short term. ${ }^{75}$

High altitude has traditionally been associated with a reduction in mite allergen exposure, a lower rate of mite sensitization, ${ }^{76}$ and an improvement in the condition of asthmatics. ${ }^{77}$ However, more recent studies have suggested that other factors could also be involved in this improvement. ${ }^{78,79}$ Overall, airborne pollen grain and fungal spore concentrations are low, thus providing favorable conditions for those who suffer from pollen allergies. ${ }^{80}$

\section{Occupational exposures}

Work-exacerbated asthma can occur when current asthma symptoms are made worse due to work; it does not refer to work as the cause of asthma. ${ }^{81}$ This phenomenon has been reported to occur in $21.5 \%$ of asthmatics who work. Dust is the most commonly implicated agent of work-exacerbated asthma in the health care and education sectors, while for service jobs, smoke is the most common agent. Work-related asthma can be triggered by specific occupational agents. According to the French network of occupational physicians, there was a significant decrease in work-related asthma over the period 2001-2009, especially in the cases of aldehyde, latex, and isocyanates exposure, but, conversely, there was a significant increase for quaternary ammonium compounds. ${ }^{82}$

Avoidance is mainly based on occupational hygiene and the use of personal protective equipment. It also relies on an adequate knowledge of the potential triggers of work-related asthma by asthmatic patients. A Canadian web-based educational tool has been developed and successfully tested with a group of asthmatic patients. ${ }^{83}$

\section{Drugs}

In a series originating from the Swiss Drug Monitoring Center, bronchospasm was reported in $2 \%$ of adverse drug reactions. ${ }^{84}$ Analgesics and nonsteroidal anti-inflammatory drugs were involved in $24 \%$ of these cases, anti-infectious in $18 \%$, cardiovascular drugs in $11 \%$, drug formulation 
agents in $9 \%$, vaccines and immunoglobulins in $5.5 \%$, plasma volume expanders in 5.5\%, and other drugs in $27 \%$. However, bronchospastic reactions should not be equated with asthmatic bronchospastic reactions because the pathogenic mechanisms underlying these reactions remain unclear.

\section{Stress and emotional disturbances}

Stress may enhance airway inflammation by modulating immune cell function through neural and hormonal pathways. Psychological triggers have been consistently associated with exacerbations and emergency treatments. ${ }^{85}$ In Puerto Rican children, caregiver depression, perceived stress, and child's negative life events were associated with high trigger scores. ${ }^{86}$ Another survey concluded that anxiety may exacerbate the effects of disrupted sleep on childhood asthma control. ${ }^{87}$ A Cochrane Database Systematic Review only found two intervention studies, and it concluded that family therapy may be a useful adjunct to medication for asthmatic children. ${ }^{88}$

\section{Food reactions}

Although food allergy is often associated with asthma, asthma is not, in and of itself, a strong predictor for fatal anaphylaxis. ${ }^{89}$

Avoidance is based on not eating offending foods and, with selected patients and a suitably skilled medical team, specific hyposensitization.

Sulfites, used as preservatives and antioxidants, are found in many foods, such as pickled foods, dried fruits, and drinks such as beer, wine, and soft drinks. They can induce allergylike symptoms such as wheezing, tightness, and cough in people with underlying asthma and allergic rhinitis..$^{90}$

\section{Recommendations from some of the national societies and national authorities}

Official recommendations regarding asthma trigger identification and management vary widely between countries. Here, we present various recommendations, sometimes contradictory, originating from national societies or national authorities. For example, the US guidelines for management of asthma exacerbations encourage "trigger identification and avoidance instructions", without providing more detailed instructions. ${ }^{91}$ The British Thoracic Society also recommends identification of triggers and emphasizes the role of passive smoking. ${ }^{92}$ The French Pulmonology Society provides a list of the main triggers. ${ }^{93}$ The American Academy of Allergy and Clinical Immunology recommends to avoid any trigger but does not mention how to do that. ${ }^{94}$
In regard to allergen avoidance, there are large discrepancies in the recommendations from National Societies. The American College of Chest Physicians recommends decreasing exposure to passive smoking, humidity and molds, pests, and noxious gas. ${ }^{95}$ The British Thoracic Society does not recommend the use of physical and chemical methods of reducing HDM levels in the home. It concludes that "studies of individual aeroallergen avoidance strategies show that single interventions have limited or no benefit" and suggest to implement "a multifaceted strategy more likely to be effective if it addresses all the indoor asthma triggers". ${ }^{93}$ The British Society on Allergy and Clinical Immunology states that HDM avoidance might be beneficial in highly motivated patients, and clinical benefits are more likely with multiple interventions. ${ }^{96}$ The French Pulmonology Society emphasizes avoiding active and passive smoking. ${ }^{93}$ It suggests that a home visit for environmental inspection could be useful for severe asthmatic patients who have failed to gain control of their condition despite optimum treatment. The Allergic Rhinitis and its Impact on Asthma (ARIA) group suggests "not to use single chemical or physical preventive methods or their combination" but rather "multifaceted environmental control to reduce exposure in patients with allergy to HDMs". ${ }^{97}$ Finally, the Global Initiative for Asthma (GINA) states that "Although allergens may contribute to asthma symptoms in sensitized patients, allergen avoidance is not recommended as a general strategy for asthma". These strategies are often complex and expensive, and there are no validated methods for identifying those who are likely to benefit. ${ }^{98}$ In summary, no scientific society recommends basic HDM avoidance procedures.

\section{Conclusion}

Many triggers, both allergenic and nonallergenic, and their interactions influence the natural history of asthma. The attending physician's task is to list them for each individual patient and to provide avoidance counseling. Educational programs are best suited to allow patient needs to be discussed and to provide answers to any question. However, in many instances, avoiding triggers is not a guarantee of success, and a multifaceted program should be implemented.

\section{Disclosure}

The authors report no conflicts of interest in this work.

\section{References}

1. Price D, Dale P, Elder E, Chapman KR. Types, frequency and impact of asthma triggers on patients' lives: a quantitative study in five European countries. JAsthma. 2014;51(2):127-135. 
2. Gent JF, Belanger K, Triche EW, Bracken MB, Beckett WS, Leaderer BP. Association of pediatric asthma severity with exposure to common household dust allergens. Environ Res. 2009;109(6):768-774.

3. Gent JF, Kezik JM, Hill ME, Tsai E, Li DW, Leaderer BP. Household mold and dust allergens: exposure, sensitization and childhood asthma morbidity. Environ Res. 2012;118(10):86-93.

4. Pollart SM, Chapman MD, Fiocco GP, Rose G, Platts-Mills TA. Epidemiology of acute asthma: IgE antibodies to common inhalant allergens as a risk factor for emergency room visits. J Allergy Clin Immunol. 1989;83(5):875-882.

5. Lewis SA, Weiss ST, Platts-Mills TA, Burge H, Gold DR. The role of indoor allergen sensitization and exposure in causing morbidity in women with asthma. Am J Respir Crit Care Med. 2002;165(7):961-966.

6. Hammarquist C, Burr ML, Gotzsche PC. House dust mite control measures for asthma. Cochrane Database Syst Rev. 2008;(2):CD001187.

7. Custovic A, Wijk PG. The effectiveness of measures to change the indoor environment in the treatment of allergic rhinitis and asthma: ARIA update (in collaboration with GA(2)LEN). Allergy. 2005;60(9):1112-1115.

8. Platts-Mills TA. Allergen avoidance in the treatment of asthma: problems with the meta-analyses. JAllergy Clin Immunol. 2008;122(4):694-696.

9. Tovey ER, Liu-Brennan D, Garden FL, Olivier BG, Perzanowski MS, Marks GB. Time-based measurement of personal mite allergen bioaerosol exposure over 24 hour periods. PLoS One. 2016;11(5):e0153414.

10. Nevalainen A, Täubel M, Hyvärinen A. Indoor fungi: companions and contaminants. Indoor Air. 2015;25(2):125-156.

11. Krieger J, Takaro TK, Allen C, et al. The Seattle-King county healthy homes project: implementation of a comprehensive approach to improving indoor environmental quality for low-income children with asthma. Environ Health Perspect. 2002;110(Suppl 2):311-322.

12. Crocker DD, Kinyota S, Dimutru GG, et al. Effectiveness of home-based, multi-trigger, multicomponent interventions with an environmental focus for reducing asthma morbidity: a community guide systematic review. Am J Prev Med. 2011;41(2 Suppl 1):S5-S32.

13. Dixon SL, Fowler C, Harris J, et al. An examination of interventions to reduce respiratory health and injury hazards in homes of low-income families. Environ Res. 2009;109(1):123-130.

14. Fisk WJ, Lei-Gomez Q, Mendell MJ. Meta-analyses of the associations of respiratory health effects with dampness and molds in homes. Indoor Air. 2007;17(4):284-296.

15. Mendell MJ, Mirer AG, Cheung K, Tong M, Douwes J. Respiratory and allergic health effects of dampness, mold, and dampness-related agents: a review of the epidemiologic evidence. Environ Health Perspect. 2011;119(6):748-756.

16. Quansah R, Jaakhola MS, Hugg TT, Heikkinen SA, Jaakkola JJ. Residential dampness and molds and the risk of developing asthma: a systematic review and meta-analysis. PLoS One. 2012;7(11):e47526.

17. Sharpe RA, Bearman N, Thornton CR, Husk K, Osborne NJ. Indoor fungal diversity and asthma: a meta-analysis and systematic review of risk factors. J Allergy Clin Immunol. 2015;135(1):110-122.

18. Institute of Medicine of the National Academies. Damp Indoor Spaces and Health, National Academy of Sciences. 2004. Available from: https://www.ncbi.nlm.nih.gov/books/NBK215643/.

19. Agence Nationale de Sécurité Sanitaire de l'Alimentation, de l'Environnement et du travail. 2016.

20. World Health Organization Regional Office for Europe. Dampness and Mould. WHO Guidelines for Indoor Air Quality. 2009. Available from: http://www.who.int/indoorair/publications/7989289041683/en/.

21. Cox-Ganser JM. Indoor dampness and mould health effects - ongoing questions on microbial exposures and allergic versus nonallergic mechanisms. Clin Exp Allergy. 2015;45(10):1478-1482.

22. American Veterinary Medical Association (AVMA) [webpage on the Internet]. U.S. Pet Ownership and Demographics Sourcebook. 2012. Available from: https://www.avma.org/KB/Resources/Statistics/ Pages/Market-research-statistics-US-pet-ownership.aspx. Accessed November 7, 2016.

23. American Pet Products Association (APPA) [webpage on the Internet]. National Pet Owners Survey, 2009-2010. Available from: http://www. pfma.com/faq.html. Accessed November 7, 2016.
24. The European Pet Food Industry Federation (FEDIAF). Facts and Figures. 2012. Available from: http://www.fediaf.org/fileadmin/ user_upload/facts_and_figures_2010.pdf. Accessed November 7, 2016.

25. Pyrhönen K, Näyhä S, Läärä E. Dog and cat exposure and respective pet allergy in early childhood. Pediatr Allergy Immunol. 2015;26(3): $247-255$.

26. Nilsson OB, van Hage M, Grönlund H. Mammalian-derived respiratory allergens - implications for diagnosis and therapy of individuals allergic to furry animals. Methods. 2014;66(1):86-95.

27. de Blay F, Heymann PW, Chapman MD, Platts-Mills TA. Airborne dust mite allergens: comparison of group II allergens with group I mite allergen and cat allergen Fel d I. JAllergy Clin Immunol. 1991;88(6):919-926.

28. Ritz BR, Hoelscher B, Frye C, Meyer I, Heinrich J. Allergic sensitization owing to 'second-hand' cat exposure in schools. Allergy. 2002;57(4): 357-361.

29. Enberg RN, Shamie SM, McCullough J, Ownby DR. Ubiquitous presence of cat allergen in cat-free buildings: probable dispersal from human clothing. Ann Allergy. 1993;70(6):471-474

30. Moira CY, Ferguson A, Dimich-Ward H, Watson W, Manfreda J, Becker A. Effectiveness of and compliance to intervention measures in reducing house dust and cat allergen levels. Ann Allergy Asthma Immunol. 2002;88(1):52-58.

31. Liccardi G, D'Amato G, Russo M, et al. Focus on cat allergen (Fel d 1): immunological and aerodynamic characteristics, modality of airway sensitization and avoidance strategies. Int Arch Allergy Immunol. 2003;132(1):1-12.

32. Karlsson AS, Renström A, Hedrén M, Larsson K. Allergen avoidance does not alter airborne cat allergen levels in classrooms. Allergy. 2004;59(6):661-667.

33. de Blay F, Chapman MD, Platts-Mills TA. Airborne cat allergen (Fel d 1). Environmental control with the cat in situ. Am Rev Respir Dis. 1991;143(6): 1334-1339.

34. Butt A, Rashid D, Lockey RF. Do hypoallergenic cats and dogs exist? Ann Allergy Asthma Immunol. 2012;108(2):74-76.

35. Sánchez J, Diez S, Cardona R. Pet avoidance in allergy cases: is it possible to implement it? Biomedica. 2015;35(3):357-362.

36. Rosenstreich DL, Eggelston P, Kattan M, et al. The role of cockroach allergy and exposure to cockroach allergen in causing morbidity among inner-city children with asthma. NEngl JMed. 1997;336(19):1356-1363.

37. National Asthma Education and Preventive Program. Expert panel report 3 (EPR-3): guidelines for the diagnosis and management of asthmasummary report 2007. J Allergy Clin Immunol. 2007;120(5 Suppl): S94-S138.

38. Morgan WJ, Crain EF, Gruchalla RS, et al. Results of a home-based environmental intervention among urban children with asthma. $N$ Engl J Med. 2004;351(11):1068-1080.

39. Sheehan WJ, Rangsithienchai PA, Muilenberg ML, et al. Mouse allergens in urban elementary schools and homes of children with asthma. Ann Allergy Asthma Immunol. 2009;102(2):125-130.

40. Phipatanakul W, Cronin B, Wood RA, et al. Effect of environmental intervention on mouse allergen levels in homes of inner-city Boston children with asthma. Ann Allergy Asthma Immunol. 2004;92(4):420-425.

41. Kattan M, Stearns SC, Crain EF, et al. Cost-effectiveness of a homebased environmental intervention for inner-city children with asthma. J Allergy Clin Immunol. 2005;116(5):1058-1063.

42. Pongracic JA, Visness CM, Gruchalla RS, Evans R 3rd, Mitchell HE. Effect of mouse allergen and rodent environmental intervention on asthma in inner-city children. Ann Allergy Asthma Immunol. 2008;101(1): $35-41$.

43. Piret $T$, Tummino $C$, Charpin $D$. Une première évaluation en France de la présence d'allergènes de rongeurs dans les bâtiments publics [A first assessment of rodent allergens in French public buildings]. Rev Fr Allergol. 2015;55(1):5-12.

44. Beier J, Beeh KM, Kornmann O, Morankic E, Ritter N, Buhl R. Dissimilarity between seasonal changes in airway responsiveness to adenosine-5'-monophosphate and methacholine in patients with grass pollen allergic rhinitis: relation to induced sputum. Int Arch Allergy Immunol. 2003;132(1):76-81. 
45. Kurt E, Aklas A, Gulbas Z, Erginel S, Arslan S. The effects of natural pollen exposure on inflammatory cytokines and their relationship with nonspecific bronchial hyperresponsiveness in seasonal allergic rhinitis. Allergy Asthma Proc. 2010;31(2):126-131.

46. Linneberg A, Henrik Nielsen N, Frølund L, et al. The link between allergic rhinitis and allergic asthma: a prospective population-based study. The Copenhagen Allergy Study. Allergy. 2002;57(11):1048-1052.

47. Fukutomi Y, Taniquchi M. Sensitization to fungal allergens: resolved and unresolved issues. Allergol Int. 2015;64(4):321-331.

48. Busse WW, Lemanske RF Jr, Gern JE. Role of viral respiratory infections in asthma and asthma exacerbations. Lancet. 2010;376(9743):826-834

49. Johnston NW, Johnston SL, Duncan JM, et al. The September epidemic of asthma exacerbations in children: a search for etiology. J Allergy Clin Immunol. 2005;115(1):132-138.

50. Murray CS, Poletti G, Kebadze T, et al. Study of modifiable risk factors for asthma exacerbations: virus infection and allergen exposure increase the risk of asthma hospital admissions in children. Thorax. 2006;61(5):376-382.

51. Centers for Disease Control and Prevention (CDC). National Center for Environmental Health. Asthma Stats: Percentage of People with Asthma Who Smoke. 2010. Available from: https://www.cdc.gov/asthma/ asthma_stats/asthma_stats_factsheet.pdf. Accessed November 7, 2016.

52. Fernandes Sde S, Andrade CR, Caminhas AP, Camargos PA, Ibiapina Cda C. Prevalence of self-reported smoking experimentation in adolescents with asthma or allergic rhinitis. J Bras Pneumol. 2016;42(2):84-87.

53. Polosa R, Thomson NC. Smoking and asthma: dangerous liaisons. Eur Respir J. 2013;41(3):716-726.

54. Murphy VE, Clifton VL, Gibson PG. The effect of cigarette smoking on asthma control during exacerbations in pregnant women. Thorax. 2010;65(8):739-744.

55. Chalmers GW, Macleod KJ, Little SA, Thomson LJ, McSharry CP, Thomson NC. Influence of cigarette smoking on inhaled corticosteroid treatment in mild asthma. Thorax. 2002;57(3):226-230.

56. McLeish AC, Farris SG, Johnson AL, Bernstein JA, Zvolensky MJ Evaluation of smokers with and without asthma in terms of smoking cessation outcome, nicotine withdrawal symptoms, and craving: findings from a self-guided quit attempt. Addict Behav. 2016;63:149-154.

57. Bittner JC, Hasegawa K, Probst BD, Mould-Millman NK, Silverman RA, Camargo CA Jr. Smoking status and smoking cessation intervention among U.S. adults hospitalized for asthma exacerbations. Allergy Asthma Proc. 2016;37(4):318-323.

58. Perret JL, Bonevski B, McDonald CF, Abramson MJ. Smoking cessation strategies for patients with asthma: improving patient outcomes J Asthma Allergy. 2016;9:117-128.

59. Office of Environmental Health Hazard Assessment. Health Effects of Exposure to Environmental Tobacco Smoke. Final Report. Sacramento: CA: EPA; 2005. Available from: http://oehha.ca.gov/air/report/ health-effects-exposure-environmental-tobacco-smoke-final-report.

60. Mackay D, Haw S, Ayres JG, Fischbacher C, Pell JP. Smoke-free legislation and hospitalizations for childhood asthma. $N$ Engl J Med. 2010;363(12):1139-1145.

61. Croghan IT, Ebbert JO, Hays JT, et al. Impact of a countywide smokefree workplace law on emergency department visits for respiratory diseases: a retrospective cohort study. BMC Pulm Med. 2015;15:6.

62. Lin HC, Park JY, Seo DC. Comprehensive US statewide smokefree indoor air legislation and secondhand smoke exposure, asthma prevalence, and related doctor visits: 2007-2011. Am J Public Health. 2015;105(8):1617-1622.

63. Been JV, Nurmatov UB, Cox B, Nawrot TS, van Schayck CP, Sheikh A. Effect of smoke-free legislation on perinatal and child health: a systematic review and meta-analysis. Lancet. 2014;383(9928):1549-1560.

64. Li S, Williams G, Jalaludin B, Baker P. Panel studies of air pollution on children's lung function and respiratory symptoms: a literature review. J Asthma. 2012;49(9):895-910.

65. McCreanor J, Cullinan P, Nieuwenhuijsen MJ, et al. Respiratory effects of exposure to diesel traffic in persons with asthma. $N$ Engl J Med. 2007;357(23):2348-2358.
66. Zheng XY, Ding H, Jiang LN, et al. Association between air pollutants and asthma emergency room visits and hospital admissions in time series studies: a systematic review and meta-analysis. PLoS One. 2015;10(9):e0138146.

67. Segala C, Fauroux B, Just J, Pascual L, Grimfeld A, Neukirch F. Shortterm effect of winter air pollution on respiratory health of asthmatic children in Paris. Eur Respir J. 1998;11(3):677-685.

68. US Environmental Protection Agency [homepage on the Internet]. Air Quality Index. Research Triangle Park. NC: 2009. Available from: https://www.airnow.gov. Accessed November 7, 2016.

69. Zhang S, Li L, Gao W, Wang Y, Yao X. Interventions to reduce individual exposure of elderly individuals and children to haze: a review. JThorac Dis. 2016;8(1):E62-E68.

70. Nurmatov UB, Tagiyeva N, Semple S, Devereux G, Sheikh A. Volatile organic compounds and risk of asthma and allergy: a systematic review. Eur Respir Rev. 2015;24(135):92-101.

71. Tunno BJ, Naumoff Shields K, Cambal L, et al. Indoor air sampling for fine particulate matter and black carbon in industrial communities in Pittsburgh. Sci Total Environ. 2015;536:108-115.

72. McAuley TR, Hopke PK, Zhao J, Babaian S. Comparison of the effects of e-cigarette vapor and cigarette smoke on indoor air quality. Inhal Toxicol. 2012;24(12):850-857.

73. Laumbach R, Meng Q, Kipen H. What can individuals do to reduce personal health risk from air pollution? JThorac Dis. 2015;7(1):96-107.

74. Kim J, Lim Y, Kim H. Outdoor temperature changes and emergency department visits for asthma in Seoul, Korea: a time-series study. Environ Res. 2014;135:15-20.

75. Zhang Y, Peng L, Kan H, et al. Effects of meteorological factors on daily hospital admissions for asthma in adults: a time-series analysis. PLoS One. 2014;9(7):e102475.

76. Ozkaya E, Sogut A, Küçükkoç M, et al. Sensitization pattern of inhalant allergens in children with asthma who are living different altitudes in Turkey. Int J Biometeorol. 2015;59(11):1685-1690.

77. Grootendorst DC, Dahlén SE, Van Den Bos JW, et al. Benefits of high altitude allergen avoidance in atopic adolescents with moderate to severe asthma, over and above treatment with high dose inhaled steroids. Clin Exp Allergy. 2001;31(3):400-408.

78. Rijssenbeek-Nouwens LH, Fieten KB, Bron AO, Hashimoto S, Bel EH, Weersink EJ. High-altitude treatment in atopic and nonatopic patients with severe asthma. Eur Respir J. 2012;40(6):1374-1380.

79. Charpin D. High altitude and asthma: beyond house dust mites. Eur Respir J. 2012;40(6):1320-1321.

80. Camacho I, Grinn-Gofroń A, Camacho R, Berenguer P, Sadyś M. Madeira-a tourist destination for asthma sufferers. Int J Biometeorol. 2016;60(11):1739-1751.

81. Tarlo SM. Update on work-exacerbated asthma. Int J Occup Med Environ Health. 2016;29(3):369-374.

82. Paris C, Ngatchou-Wandji J, Luc A, et al; Members of the RNV3P Work-related asthma in France: recent trends for the period 2001-2009. Occup Environ Med. 2012;69(6):391-397.

83. Lipszyc JC, Gotzer S, Scarborough J, Liss GM, Gupta S, Tarlo SM. Evaluation of the efficacy of a web-based work-related asthma educational tool. J Asthma. 2016;53(10):1071-1075.

84. Leuppi JD, Schnyder P, Hartmann K, Reinhart WH, Kuhn M. Druginduced bronchospasm: analysis of 187 spontaneously reported cases. Respiration. 2001;68(4):345-351.

85. Ritz T, Wittchen HU, Klotsche J, Mühlig S, Riedel O; sap-NEEDS study group. Asthma trigger reports are associated with low quality of life, exacerbations, and emergency treatments. Ann Am Thorac Soc. 2016;13(2):204-211.

86. Martin MA, Thomas AM, Mosnaim G, Greve M, Swider SM, Rothschild SK. Home asthma triggers: barriers to asthma control in Chicago Puerto Rican children. J Health Care Poor Underserved. 2013;24(2):813-827.

87. Daniel LC, Boergers J, Kopel SJ, Koinis-Mitchell D. Missed sleep and asthma morbidity in urban children. Ann Allergy Asthma Immunol. 2012;109(1):41-46.

88. Yorke J, Shuldham C. Family therapy for chronic asthma in children. Cochrane Database Syst Rev. 2005;(2):CD000089. 
89. Turner PJ, Baumert JL, Beyer K, et al. Can we identify patients at risk of life-threatening allergic reactions to food? Allergy. 2016;71(9):1241-1245.

90. Vally H, Misso NL, Madan V. Clinical effects of sulphite additives. Clin Exp Allergy. 2009;39(11):1643-1651.

91. Camargo CA Jr, Rachelefsky G, Schatz M. Managing asthma exacerbations in the emergency department: summary of the National Asthma Education and Prevention Program Expert Panel Report 3 guidelines for the management of asthma exacerbations. Proc Am Thorac Soc. 2009;6(4):357-366.

92. Guidelines [webpage on the Internet]. British Guidelines on the Management of Asthma in Adults. Available from: http://www.guidelines. co.uk/btssign/asthma-in-adult. Accessed November 7, 2016.

93. Raherison C, Bourdin A, Bonniaud P, et al. Updated guidelines (2015) for management and monitoring of adult and adolescent asthmatic patients (from 12 years and older) of the Sociéte de pneumologie de langue française (SPLF) (summary). Rev Mal Respir. 2016;33(4):271-278.
94. American Academy of Allergy Asthma and Immunology [homepage on the Internet]. Available from: www.aaaai.org. Accessed November 7, 2016.

95. American College of Chest Physician and the Chest Foundation. Controlling Your Asthma. Available from: http://www.med.umich.edu/1 info/ FHP/practiceguides/asthma/chestpt.pdf. Accessed November 7, 2016.

96. Scadding GK, Durham SR, Mirakian R, et al; British Society for Allergy and Clinical Immunology. BSACI guidelines for the management of allergic and non-allergic rhinitis. Clin Exp Allergy. 2008;38(1):19-42.

97. Brozek JL, Bousquet J, Baena-Cagnani CE, et al; Global Allergy and Asthma European Network; Grading of Recommendations Assessment, Development and Evaluation Working Group. Allergic rhinitis and its impact on asthma (ARIA) guidelines: 2010 revision. J Allergy Clin Immunol. 2010;126(3):466-476.

98. Global Initiative on Asthma [homepage on the Internet]. Available from: www.gina.org. Accessed November 7, 2016.
Journal of Asthma and Allergy

\section{Publish your work in this journal}

The Journal of Asthma and Allergy is an international, peer-reviewed open access journal publishing original research, reports, editorials and commentaries on the following topics: Asthma; Pulmonary physiology; Asthma related clinical health; Clinical immunology and the immunological basis of disease; Pharmacological interventions and

\section{Dovepress}

new therapies. This journal is included in PubMed. The manuscrip management system is completely online and includes a very quick and fair peer-review system, which is all easy to use. Visit http://www dovepress.com/testimonials.php to read real quotes from published authors. 